\title{
Utilization of ground coloured glass cullet in construction materials
}

\author{
A. Karamberi \& A. Moutsatsou \\ Chemical Engineering Department, \\ National Technical University of Athens, Greece
}

\begin{abstract}
Due to the imperative need for recycling, the present study was focused on the exploitation of domestic and industrial waste and particularly of finely ground glass cullet in three applications of structural materials. Firstly, the possible use of glass cullet in cementitious materials either as a binder, aggregate or filler was studied. A second study sector was the utilization of glass cullet for the production of foam glass. The particle size effect of glass cullet and the influence of the type and content of foaming agent at the final product were examined. And finally, the vitrification by thermal treatment of industrial waste (fly ashes and slag) with or without the presence of glass cullet and the further crystallization of the glassy products for the production of glass-ceramics was studied.
\end{abstract}

Keywords: glass cullet, fly ash, slag, vitrification, foam glass.

\section{Introduction}

The utilization of waste glass in industrial applications in which no strict requirements of purity are requested is well-known. Recent works pointed out the feasibility of glass as filler in road paving or cementitious products or as a batch addition in the melting of hazardous wastes. The development of foam glass is also particularly attractive, since large amounts of waste could be employed as raw materials for a very marketable product. Moreover, the utilization of glass cullet as well as industrial by-products for the production of glass and glass-ceramics is possible [1,2]. 
A typical pozzolanic material features three characteristics, is rich in silica, is an amorphous material and has a large surface area. Glass is an amorphous material and has high silica content. Therefore glass might satisfy the basic requirements for a pozzolan if it is ground to a size fine enough so as to pacify the alkali-silica reaction and to activate the pozzolanic behaviour.

Glass-ceramics prepared by controlled devitrification of glasses were developed in the $1950 \mathrm{~s}$ and find a wide variety of applications such as microelectronic substrates and packaging, optically transparent components as well as for the matrix of composite materials [3].

The glass-ceramics were produced by conventional glass route and subsequently crystallized, usually by heat treatment in two stages to give nucleation followed crystal growth. For glass-ceramic production via glass processing, nuclei must readily form throughout the bulk of the parent glass, surface nucleation is to be avoided as it is usually detrimental to mechanical performance [4].

Additionally, the possible use of waste glass for the production of lightweight granules has been studied. As foaming agent, $\mathrm{MnO}_{2}$ and $\mathrm{SiC}$ were chosen. Granules have been prepared by mixing together finely ground waste glass with the foaming agent and fired at different temperatures above the softening point of glass. Within the temperature range the foaming agent degas and the resulting gasses remain trapped in the glass structure. The granules structure is evaluated using Scanning Electron Microscopy.

Foam glass is produced by adding foaming agents to finely ground glass and fired at a temperature above the glass softening point. This temperature is then maintained so that the gas released by the foaming agent is captured in the glass structure, forming a lot of small pores. In the case of agents containing carbon i.e. $\mathrm{SiC}$ the agent reacts with the glass or atmosphere, forming gases which also remain captured in glass structure.

In the present study there was an effort in utilizing glass cullet in various applications. The first series of experiments is dealing with the use of glass cullet in construction materials and especially in cementitious materials either as aggregate, filler or as pozzolanic material. Moreover, glass cullet is used as a secondary raw material in the production of glass and glass-ceramics from four industrial by-products two lignite fly ashes and two slags. In the final application glass cullet is used as the primary raw material for the production of foam glass. The results are very encouraging and open the way for the sustainable utilization of industrial and domestic wastes.

\section{Experimental part}

\subsection{Materials}

The used glass cullet derived from the internal recycling of a glass industry and especially from glass bottle containers. The three most common cullet colours, green, amber and flint, were used in order to evaluate the influence of the colour of the glass in the cement mixtures. 
Four industrial wastes were selected: i) two fly ashes, of different chemical and mineralogical composition, derived from the combustion of lignite and originated from Megalopoli and Ptolemais area in Greece. Greek fly ashes are classified as Calcareous Fly Ashes (C according to ASTM), as having a large content of $\mathrm{CaO}$, exceeding $10 \%$, ii) an electric furnace slag derives from a smelting plant for the pyrometallurgical treatment of laterite ore for the production of sponge Ferro-nickel containing $18-25 \% \mathrm{Ni}$, iii) an electric arc furnace slag from the production of steel. The specific steel making plant uses scrap as a raw material.

The chemical composition of glass cullet and industrial waste is shown in Table 1.

Table 1: Chemical composition of cullet, fly ashes and slags.

\begin{tabular}{|c|c|c|c|c|c|c|c|}
\hline $\begin{array}{l}\% \\
(w / w)\end{array}$ & $\begin{array}{l}\text { Electric } \\
\text { Furnace } \\
\text { Fe-Ni } \\
\text { Slag }\end{array}$ & $\begin{array}{l}\text { Electric } \\
\text { Furnace } \\
\text { Steel } \\
\text { Slag }\end{array}$ & $\begin{array}{l}\text { Lignite } \\
\text { Meg. } \\
\text { Fly } \\
\text { Ash }\end{array}$ & $\begin{array}{l}\text { Lignite } \\
\text { Ptol. } \\
\text { Fly } \\
\text { Ash }\end{array}$ & $\begin{array}{l}\text { Amber } \\
\text { cullet }\end{array}$ & $\begin{array}{l}\text { Green } \\
\text { cullet }\end{array}$ & $\begin{array}{l}\text { Flint } \\
\text { cullet }\end{array}$ \\
\hline $\mathrm{FeO}$ & 41.10 & 17.00 & - & - & - & - & \\
\hline $\mathrm{Fe}_{2} \mathrm{O}_{3}$ & 2.60 & - & 8.44 & 5.10 & 0.35 & 0.45 & 0.45 \\
\hline $\mathrm{MnO}$ & - & 7.50 & - & - & - & - & \\
\hline $\mathrm{Ni}-\mathrm{Co}$ & 0.14 & - & - & - & - & - & \\
\hline $\mathrm{SiO}_{2}$ & 33.70 & 16.00 & 51.26 & 30.16 & 71.20 & 70.50 & 70.65 \\
\hline $\mathrm{CaO}$ & 3.30 & 41.00 & 11.82 & 34.99 & 10.35 & 10.15 & 10.70 \\
\hline $\mathrm{MgO}$ & 3.40 & 4.50 & 2.27 & 2.69 & 2.60 & 2.75 & 2.45 \\
\hline $\mathrm{Al}_{2} \mathrm{O}_{3}$ & 9.30 & 7.00 & 19.39 & 14.93 & 1.90 & 1.80 & 1.75 \\
\hline $\mathrm{Na}_{2} \mathrm{O}$ & - & - & 0.53 & 1.01 & 13.15 & 12.95 & 13.25 \\
\hline $\mathrm{K}_{2} \mathrm{O}$ & - & - & 1.81 & 0.4 & 0.60 & 0.45 & 0.55 \\
\hline $\mathrm{Cr}_{2} \mathrm{O}_{3}$ & 4.30 & 0.56 & - & - & 0.06 & 0.25 & - \\
\hline $\mathrm{SO}_{3}$ & 0.85 & 6.63 & 2.91 & 6.28 & 0.30 & 0.25 & 0.45 \\
\hline
\end{tabular}

Green, amber and flint containers were ground in a roller mill and in a mortar grinder and separated into the appropriate fractions depending on the application. The slag was ground in ball mills and their particles passed the $90 \mu \mathrm{m}$ sieve (DIN 4188). The fineness of fly ash is measured using Laser Granulometre (CILAS GRANULOMETRE 715 D314) and it was found that Megalopolis fly ash samples have a retained amount of $60 \%$ on $48 \mu \mathrm{m}$, while Ptolemais fly ash samples have an average retained amount of $25 \%$ on $48 \mu \mathrm{m}$.

Ordinary Portland Cement (OPC) and sand according to ASTM C778 were used for the pastes and the mortars. A solution of $\mathrm{NaOH} 1 \mathrm{M}$ was used as alkali activator.

The X-ray analysis XRD (Siemens D5000 diffractometer, $\mathrm{Cu}$ Ka radiation, Ni Filter) of the glass cullet and electric furnace Fe-Ni slag spectrums revealed an amorphous material, while the spectrums of both fly ashes and electric furnace steel slag presented as well crystalline phases. 


\subsection{Experimental procedure}

For the production of cement mortars the used glass cullet is ground and separated in two fractions: $-200 \mu \mathrm{m}+90 \mu \mathrm{m}$ and $-90 \mu \mathrm{m}$, so as to study the influence of the granulometry of glass in the mixtures.

In order to evaluate the colour effect on the hydration of cement paste and the degree of substitution of cement by cullet, glass-cement pastes and mortars were prepared with the $-90 \mu \mathrm{m}$ glass fraction fluctuating from $5 \%$ to $25 \%$ by volume. Additional samples containing 5\% glass cullet and 5\% fly ash were prepared in order to examine the potential promote of pozzolanic activity due to the presence of a highly reactive material. For the production of cement plasters glass cullet is separated in fractions similar to the conventional aggregates.

In order to estimate the pozzolanicity of glass cullet as well as of fly ashes and mixtures of fly ash and cullet Chapelle test is carried out [5]. All the sediments of the above test were examined using X-Ray Diffraction (Siemens D5000 diffractometer, $\mathrm{Cu}$ Ka radiation, Ni Filter) and Thermal Analysis TG (Mettler TGA/SDTA851 ${ }^{\mathrm{e}}$ ).

The potential alkali-silica reaction of the mortars containing cullet was assessed according to ASTM C1260. Specimens have been prepared with 25\% substitution of cement by cullet of each colour having a granulomentry $90 \mu \mathrm{m}$. The used aggregates were according to ASTM C778 and are not prone to alkalisilica reaction.

Common masonry plasters with white cement was selected in order to evaluate the influence of glass cullet in widely used commercial cementitious products. All samples were prepared using flint, green and amber glass cullet as a partial replacement for both aggregate and filler.

The properties under examination, except from the mechanical strength measurements, were the properties of the fresh plasters. In particular, retained water (EN 1015-8), air content (EN 1015-7), specific weight (EN1015-6) and table flow tests (EN 1015-3) were estimated.

For the production of foam glass, glass cullet was powdered and separated by screening into fractions of 312-250 $\mu \mathrm{m}, 250-200 \mu \mathrm{m}, 200-160 \mu \mathrm{m}, 190-90 \mu \mathrm{m}$, 90-71 $\mu \mathrm{m}, 71-45 \mu \mathrm{m},<45 \mu \mathrm{m}$. The foaming agents used were $\mathrm{SiC}$ and $\mathrm{MnO}_{2}$ with an average grain size of $45 \mu \mathrm{m}$ and added for an amount $1-5 \% \mathrm{wt}$.

Soda lime glass and foaming agents were dry mixed and compacted by light cold pressing before being subjected to the heating treatment. The optimal thermal treatment adopted was heating up to $900^{\circ} \mathrm{C}$ with rate of $10^{\circ} \mathrm{C} / \mathrm{min}$, and holding at that temperature for $30 \mathrm{~min}$, followed by heating to $950^{\circ} \mathrm{C}$ and holding for $30 \mathrm{~min}$.

For the production of glass and glass-ceramic approximately $60 \mathrm{~g}$ of each waste were placed in fire resistant ceramic crucible and heated in air at $1450^{\circ} \mathrm{C}$ for $2 \mathrm{~h}$. The resulted melt poured in a mould and allowed to cool to room temperature. The compositions of the batches are shown in table 2. Glassceramics were prepared by sintering of the glasses in air at a temperature in the range 900 to $1000^{\circ} \mathrm{C}$, held for $120 \mathrm{~min}$ and then cooled to room temperature. After heat treatment, the samples were ground to a particle size $<45 \mu \mathrm{m}$ and Xray diffraction data were obtained. 
Table 2: $\quad$ Percentage of the raw materials used in every specimen for the production of glass and glass-ceramics.

\begin{tabular}{|c|c|c|c|c|c|c|c|c|}
\hline$\%$ & G-1 & G-2 & G-3 & G-4 & G-5 & G-6 & G-7 & G-8 \\
\hline $\begin{array}{c}\text { Lignite } \\
\text { Megalopolis Fly } \\
\text { Ash }\end{array}$ & 100 & 80 & 60 & & & & & \\
\hline $\begin{array}{c}\text { Lignite Ptolemais } \\
\text { Fly Ash }\end{array}$ & & & & 100 & 80 & & & \\
\hline $\begin{array}{c}\text { Electric Furnace } \\
\text { Fe-Ni Slag }\end{array}$ & & & & & & 100 & & \\
\hline $\begin{array}{c}\text { Steel Slag } \\
\text { Amber glass }\end{array}$ & 20 & & & & & & & \\
\hline Green glass & & & & & 20 & & & \\
\hline
\end{tabular}

In order to characterize the produced glass and glass ceramics based on its physicochemical characteristics, samples hardness was measured.

In order to comply with current legislation a low leachability of hazardous components from the glass or glass-ceramic matrix must be achieved. Therefore, leaching tests were performed on both glass and glass - ceramics according to DIN 38414 S4.

The ability of produced glassy materials to be crystallized is assessed by differential thermal analysis. The crystalline phase composition of the produced glasses and glass ceramics was investigated using X-ray powder diffraction.

In order to estimate the resistance of the produced glass to chemical attack the standard test method for the resistance of glass containers to chemical attack (ASTM C 225-85) was employed.

\section{Results and discussion}

The results of the compressive strength of the mortar prisms showed that the ones with $90 \mu \mathrm{m}$ glass cullet perform better behavior than $200 \mu \mathrm{m}$ cullet [5].

The outcomes of pozzolanic reaction, according to the Chapelle test, are reinforced by the compressive strength. It is obvious that the two Greek fly ashes performed better behaviour that the glass cullet, which also performed lower pozzolanicity. It is worthy to mention that fly ash has smaller particle size in comparison to used glass cullet, which is a factor immediate associated with the reactivity of the materials. It was apparent that the green and the flint glass perform better behaviour than both the amber glass and mixed colour. Therefore, the development of the pozzolanic activity is not only influenced by the granulomentry but also by the chemical structure [6]. 
Very promising was the lack of expansion due to the alkali-silica reaction. All specimens who underwent the ASTM C1260 test exhibited minus expansion in comparison with the blank specimen [5].

In order to evaluate the maximum percentage of substitution, mortars were made containing up to $20 \%$ glass cullet. The granulometry of $90 \mu \mathrm{m}$ is selected own to the better performance of finely ground glass. The results indicated that the maximum substitution of cement in mortars is $15 \%$ when $90 \mu \mathrm{m}$ ground glass cullet is used (Figure1). Pastes containing cement-glass-fly ash performed high compressive strength at 28 days, while the opposite outcomes aroused at 360 days (Figure 2), a fact which is under further investigation.

Unexpectedly, the activated samples performed lower compressive strength than the non-activated ones. An explanation might be the low molarity of the alkali solution [7].

The application of the glass cullet in the cementitious plasters significantly improved their compressive strength, especially when it was used as filler in white cement plasters, without any notable affection to the properties of the fresh mortars. A negative factor was the decrease of the fresh glass-cement plaster workability. This phenomenon might be owed to the angular shape of the glass particles, which favours the creation of interlocks and consequently decrease the workability of the produced plasters [8].

$\mathrm{SiC}$ powder was found to be very effective in producing foamed glass when mixed to the glass powder with a concentration ranging from 1 to $5 \%$ by wt (Figure 3). The oxidation of $\mathrm{SiC}$ is the main reason of powdered glass cullet foaming. The final structure of the foamed glass is depending on the variation of glass viscosity to temperature, the heating rate, the access of oxygen to the SiC powder and the glass powder size. It was shown that the foaming process is halted if particles of glass waste are coarse. As the particle size of the glass cullet is decreasing the expansion of the pallet, the homogeneity of the final material is increasing. The results of the pallet with $\mathrm{MnO}_{2}$ are not similarly satisfying. The final product acquired a black colour and inhomogeneity of the size and the pore distribution could be observed.

The obtained highly porous material can serve as an aggregate in the production of lightweight concrete or as a trench filling material for thermal insulation.

Concerning glass and glass-ceramic production, the X-ray analysis revealed that all the products after the thermal treatment at $1450^{\circ} \mathrm{C}$ were amorphous except from those derived from $\mathrm{Fe}-\mathrm{Ni}$ slag. It is possible that $\mathrm{Fe}-\mathrm{Ni}$ slag produces crystalline phases during the thermal treatment at $1450^{\circ} \mathrm{C}$.

In figure 4 all the $\mathrm{x}$-ray diffraction spectrums of the crystallized glasses at $1000^{\circ} \mathrm{C}$ are illustrated. Due to the crystallization of $\mathrm{Fe}-\mathrm{Ni}$ slag at $1450^{\circ} \mathrm{C}$ not district changes are observed during the de-vitrification process.

Regarding glass-ceramics from vitrified Megalopolis Lignite Fly Ash the main crystalline phase that could be recognized from the XRD spectrums is anorthite. All the vitrified mixtures with Electric Furnace Steel Slag have shown analogous crystalline formation. The main crystalline phases were diopside, anorthite and albite calcian. The resulted glass-ceramic from Lignite Fly Ash and 
Electric Furnace Steel Slag was alike to that made from Electric Furnace Steel Slag. Nevertheless, the addition of glass cullet seems to deduct the crystallization, as could be revealed from the spectrum of G-1 sample compared to sample G-2. This phenomenon may occur due to the presence of $\mathrm{Na}_{2} \mathrm{O}$ and $\mathrm{K}_{2} \mathrm{O}$ in the glass cullet as fluxes which it is possible to suppress crystallization.

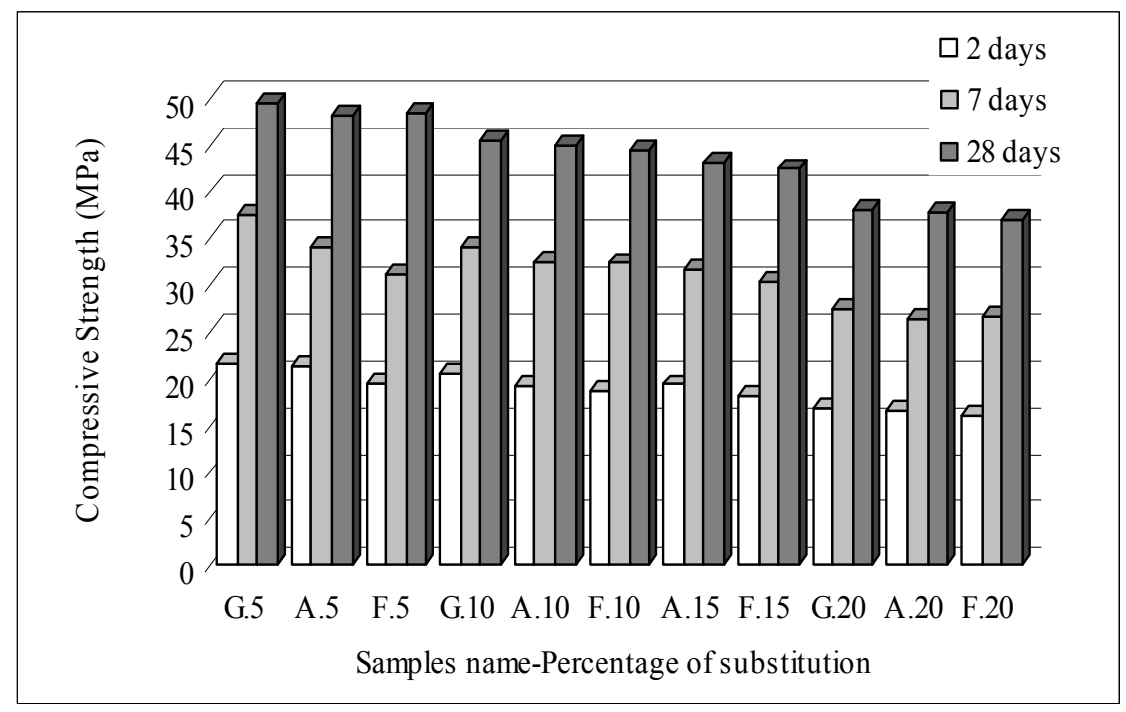

Figure 1: Compressing strength of mortar prisms.

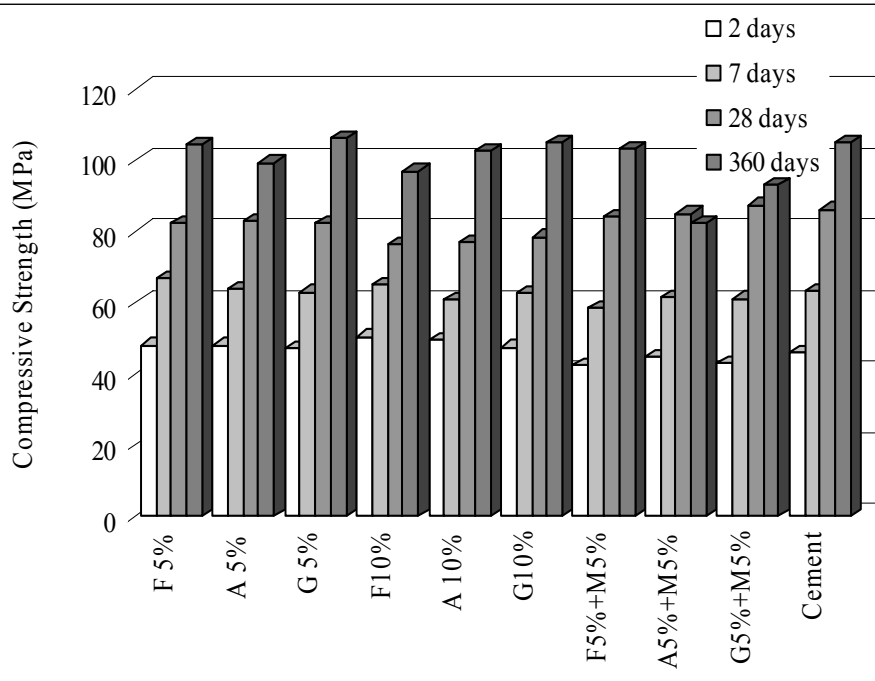

Name of the sample-percentage of substitution

Figure 2: Compressive strength of the pastes at 2, 7, 28, 360 days. 

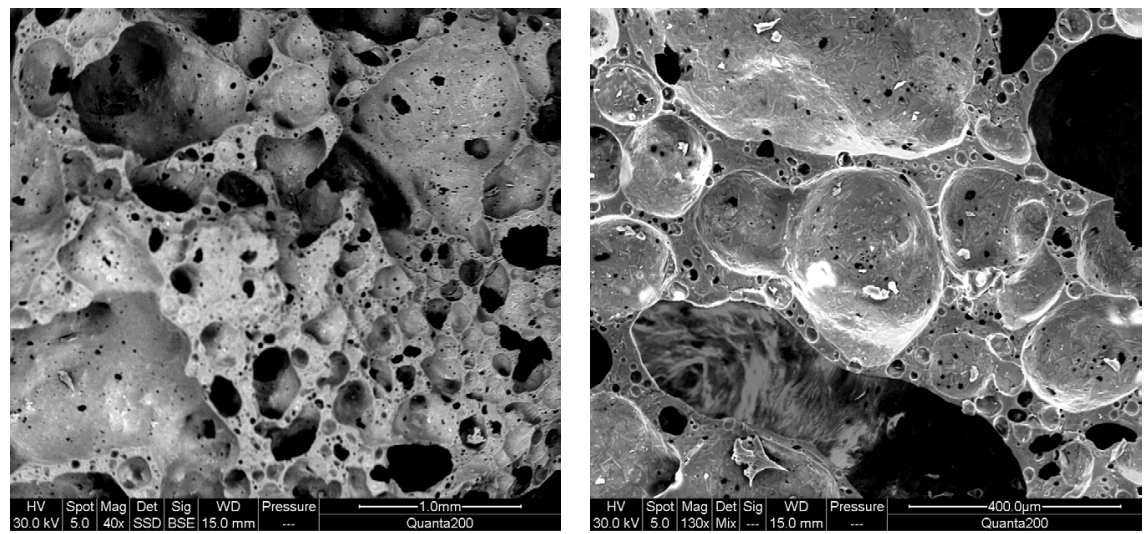

Figure 3: $\quad$ Foam glass produced by $90 \mu \mathrm{m}$ glass cullet with $3 \% \mathrm{SiC}$.

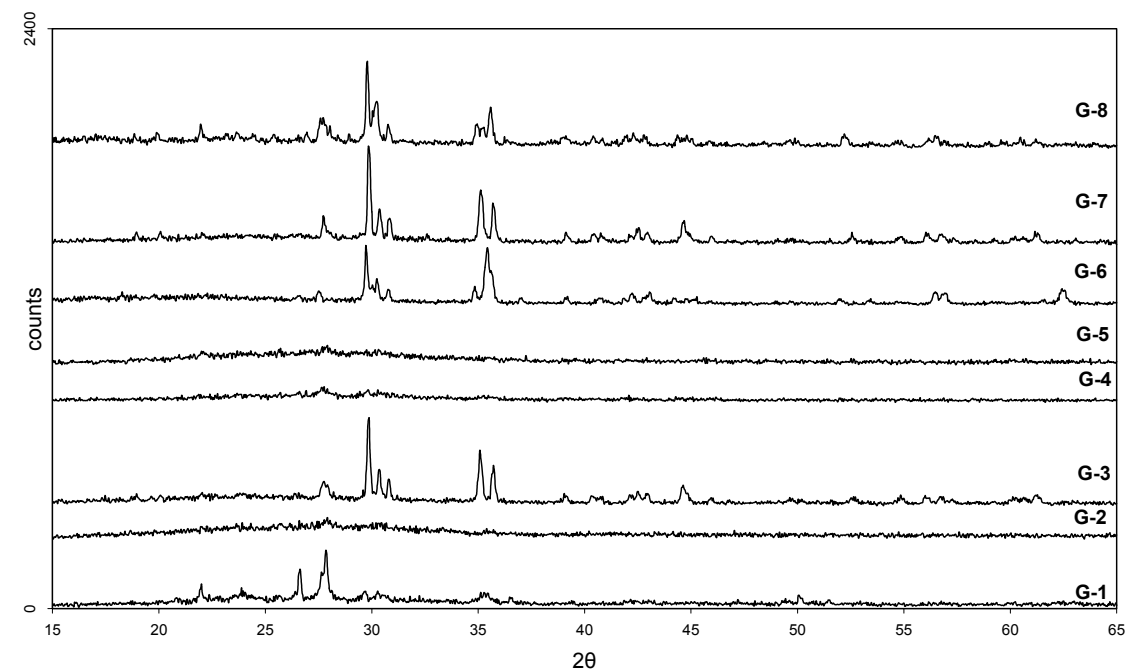

Figure 4: XRD spectrums of the produced glass-ceramics (devitrification at $\left.1000^{\circ} \mathrm{C}\right)$.

Concerning Ptolemais Lignite Fly Ash specimens, no tendency towards crystallization is observed.

The development of well crystallized crystals in the glass-ceramics can improve their mechanical strength. Moreover, diopside is the preferable crystalline phase than anorthite from the viewpoint of the mechanical properties of these glass-ceramics [9].

There was no significant leachability of all the samples, according to DIN $38414 \mathrm{~S} 4$, for $\mathrm{Cr}, \mathrm{Mn}, \mathrm{Ni}, \mathrm{Cd}, \mathrm{Cu}, \mathrm{Fe}, \mathrm{Zn}$, but concerning the leaching of $\mathrm{Fe}$, $\mathrm{Mn}$, it was not negligible, possible due to the extra fine granulometry of the testing material. All values were under the limits of the European Legislation. 
Moreover, the results of the resistance of glass to chemical attack were similar to soda lime flint glass, which shows an average value $7.67 \mathrm{~mL}$ sulphuric acid per $10 \mathrm{~g}$ glass. The higher values have been received from the vitrified $\mathrm{Fe}-\mathrm{Ni}$ slag which in some samples slopped the limits. An explanation is the incapability of the aforementioned slag to be vitrified. The presence of glass formers and modifiers is needed in order the desirable vitrification is achieved.

The glasses derived from the slags exhibited higher hardness values. The devitrification process seems to favours the hardness of the final product. As it was prospective, no alteration of the $\mathrm{Fe}-\mathrm{Ni}$ slag hardness, during the devitrification process was observed.

\section{Conclusions}

Finely ground coloured glass cullet could be used as a partial substitute of cement in mortars especially for substitutions up to $15 \%$. The green and the flint cullet performed a better behaviour than the amber glass. More satisfactory were the outcomes from the cullet application as an aggregate or as filler in cementitious plasters, with a negative factor, the reduction of workability of the fresh plaster. The utilization of cullet in white cement plasters revealed final products with increased mechanical strength. As a final conclusion, the utilization of glass cullet in cementitious materials seems feasible especially for decorative products.

Moreover, waste glass can serve as raw material for the production of lightweight aggregate. The parameters which have important influence on the foaming process are the particle size of the starting material, foaming agents and the temperature range of foaming. The selected additives $\mathrm{MnO}_{2}$, and $\mathrm{SiC}$ were proven to be suitable for the foaming of glass; among them $\mathrm{SiC}$ was the best resulting in highly porous structure.

In addition the possibility of fabricating sintered glass-ceramics from vitrified industrial waste that was capable of bulk crystallization has been demonstrated. Suitable glasses and glass-ceramics can be obtained only if the proper ratio between glassy network former and modifier elements exists.

The present work tried to demonstrate several applications for the utilization of glass cullet. Whilst economic and technical factors may ultimate exclude some of these outlets, it is essential that this diversity is preserved wherever possible if a dynamic and sustainable market is to be created for the material.

\section{References}

[1] Dhir, R.K, Dyer, T.D, Maximising Opportunities for Recycling Glass, Proc Inter Conf Sustainable Waste Management and Recycling: Glass Waste, eds. M. C. Limbachiya, J.J. Roberts, Thomas Telford: Kingston University, London, pp. 1-16, 2004

[2] Meyer, C., Recycled glass- from waste material to valuable resources, Proc.Int.Symp. Recycling and Reuse of Glass Cullet, eds. R. K. Dhir, M. 
C. Limbachiya, T. D. Dyer, Thomas Telford: Dundee,UK, pp. 179-188, 2001 .

[3] Strnad, Z., Glass-Ceramic Materials, Glass science and technology v.8, Elsevier, 1986

[4] Frugier, P., Godon, N., Vernaz, E., Larche, F., Influence of composition variations on the initial alteration rate of vitrified waste incineration flyash, Waste Management, 22, pp. 137-142, 2002.

[5] Moutsatsou, A., Chaniotakis, E., Papageorgiou, D., Karamberi, A.: Treatment and Recycling of Vitrified Fly Ash and Coloured Cullet in Cement Mixtures, Proc. of the International Congress Rec'2002, Geneva, February 2002

[6] Moutsatsou, A., Chaniotakis, E., Papageorgiou, D., Karamberi, A., Participation of coloured cullet to the hydration and the development of compressive strength of cement, Proc. of the Sixth International Conference on Concrete Technology for Developing Countries, eds. M. Resheidat, al-Balqa: Amman, Jordan, pp. 43-50, 2002.

[7] Moutsatsou, A., Kerimis, M., Karamberi A., Pozzolanic Behaviour of Glass Cement and Glass Cement Activated Mixtures, Proc. of the 7th Inter. Confer. on Concrete Technology, eds. H. Al-Mattarneh, A. Ibrahim, Z. Ahmad, UPENA: Kuala Lumpur, Malaysia, pp. 147-156, 2004.

[8] Karamberi, A., Chaniotakis, E., Papageorgiou, D., Moutsatsou, A., Application of Glass Cullet in Cement Mortars, Proc. of the 7th Inter. Confer. on Concrete Technology, eds. H. Al-Mattarneh, A. Ibrahim, Z. Ahmad, UPENA: Kuala Lumpur, Malaysia, pp. 157-164, 2004.

[9] Toya T., Kameshima Y., Yasumori A., Okada K., Preparation and properties of glass-ceramics from wastes (Kira) of silica sand and kaolin clay refining, J. Eur. Ceram. Soc., 24, pp. 2367-2372, 2004. 